\title{
Liver Cirrhosis Investigation Using Abdominal Ultrasound as Gold Standard Test and Some Bioclinical Markers with Different Levels of Diagnostic Accuracy in Chronic Liver Disease Patients between 1990 and 2004 at Teaching Hospital of Kinshasa, Democratic Republic of the Congo
}

\author{
Serge Malenga Mpaka1,2, Aliocha Nkodila Natuhoyila1,3*, Michel Lelo Tshikwela², \\ Sébastien Mbendi Nsukini ${ }^{4}$, Charles Mbendi Nlombi ${ }^{4}$, Simon Mbungu Fuele1, \\ Antoine Tshimpi Wola Yaba ${ }^{4}$, Venant Tchokonte-Nana ${ }^{5}$, Augustin Nge Okwe ${ }^{5}$, \\ Ingrid Cecile Djuikoue5, Etienne Mokondjimobe'1, Benjamin Longo-Mbenza1,6 \\ ${ }^{1}$ Department of Public Health, Lomo University of Research, Kinshasa, DR Congo \\ ${ }^{2}$ Department of Radiology, University of Kinshasa, Kinshasa, DR Congo \\ ${ }^{3}$ Department of Family Medicine and Primary Care, University of Protestante in Congo, Kinshasa, DR Congo \\ ${ }^{4}$ Department of Hepato-Gastroenterology, University of Kinshasa, Kinshasa, DR Congo \\ ${ }^{5}$ Anatomy and Comparative Anatomopathology, University of Montagnes, Bangangte, Cameroon \\ ${ }^{6}$ Department of Cardiology, University of Kinshasa, Kinshasa, DR Congo \\ Email: *nkodilaaliocha@gmail.com
}

How to cite this paper: Mpaka, S.M., Natuhoyila, A.N., Tshikwela, M.L., Nsukini, S.M., Nlombi, C.M., Fuele, S.M., Yaba, A.T.W., Tchokonte-Nana, V., Okwe, A.N., Djuikoue, I.C., Mokondjimobe, E. and Longo-Mbenza, B. (2021) Liver Cirrhosis Investigation Using Abdominal Ultrasound as Gold Standard Test and Some Bioclinical Markers with Different Levels of Diagnostic Accuracy in Chronic Liver Disease Patients between 1990 and 2004 at Teaching Hospital of Kinshasa, Democratic Republic of the Congo. Open Access Library Journal, 8: e8070.

https://doi.org/10.4236/oalib.1108070

\begin{abstract}
Liver cirrhosis (LC) is an ultimate phase of chronic liver disease. The information from the abdominal ultrasound (aUS) is one of complementary biological and clinical tests of LC assessment in the lack of liver biopsy. The aim of this study was to compare levels of diagnostic accuracy of some bio-clinical markers for LC detection using an abdominal ultrasound as a surrogate Gold standard. This was a mixed approach of consecutive patients treated for gut diseases between 1990 and 2004 at Lomo Center. LC diagnosed by aUS and confirmed by histopathology was compared to LC diagnosed by Bioclinical tests under ROC, Chi-Square, and Logistics regression (for accuracy diagnosis, Sensitivity, Specificity, AUC, and kappa) at $\mathrm{p}<0.05$. Out all aged $47.8 \pm$ 14.3 years, $71 \%$ men and $29 \%$ women with sex ratio of $3 \mathrm{M}: 1 \mathrm{~W}$ were evaluated. The prevalent aUS LC cirrhosis was $43.5 \%$. Only excessive alcohol intake
\end{abstract}


Received: October 12, 2021

Accepted: November 27, 2021

Published: November 30, 2021

Copyright (C) 2021 by author(s) and Open Access Library Inc.

This work is licensed under the Creative Commons Attribution International License (CC BY 4.0).

http://creativecommons.org/licenses/by/4.0/
$(\mathrm{aOR}=3.5 ; 95 \% \mathrm{CI} 1.4-8.8)$, leg oedema $(\mathrm{aOR}=5.3 ; 95 \% \mathrm{CI} 2.2-12.8)$, and icicle sign (aOR $=15.1 ; 95 \%$ CI 5.2 - 44) were the most important and significant independent determinants of aUS LC. For more, only ERS $\geq 60 \mathrm{~mm} / 1^{\text {st }}$ $\mathrm{H}(\mathrm{aOR}=10.5 ; 95 \% \mathrm{CI} 1.3-82.4 ; \mathrm{P}=0.025), \mathrm{AST} \geq 60 \mathrm{IU} / \mathrm{L}(\mathrm{aOR}=10.4$; $95 \%$ CI $1.3-84)$, indirect bilirubin $\geq 2 \mathrm{mg} / \mathrm{dL}(\mathrm{aOR}=6.7 ; 95 \%$ CI $1-44.7)$, prothrombin $<60 \%(\mathrm{aOR}=12 ; 95 \%$ CI $1.7-86.8)$, haemoglobin $<10 \mathrm{gr} / \mathrm{dL}$ $(\mathrm{aOR}=17 ; 95 \% \mathrm{CI} 1.4-202)$, and $\mathrm{NLR} \geq 3(\mathrm{aOR}=38.4 ; 95 \%$ CI $3.2-456)$ were the most significant and important independent determinants of aUS LC. The non-invasive aUS combined with the current clinical spectrum and biomarkers might be used as a surrogate Gold standard test for the management of chronic liver disease in poor Central Africa.

\section{Subject Areas}

Internal Medicine

\section{Keywords}

Ultrasound, Liver Cirrhosis, Haematological and Biochemical Tests, Diagnostic Performance, Central Africa

\section{Introduction}

The importance of liver in the metabolism and the haemostasis is very well established whereas Liver cirrhosis (LC), a public health issue worldwide, is an ultimate stage of chronic liver disease [1] [2] [3]. The burden and the underlying causes of LC were reported 4 years ago worldwide: the prevalence of LC had increased $74.53 \%$ from 1990 to 2017 with ASR increasing 0.75 per year in emerging countries (middle-high and high socio-demographic index in particular). In older publications from France, the prevalence of LC is estimated between 2000 and 3300 cases per million inhabitants, with an annual incidence of 150 to 200 cases per million, the number of deaths estimated at 1500 per year, and main causes such as excessive Alcohol intake (50\% to 75\%), Hepatitis virus C infection (15\% to 25\%), and Hepatitis B virus infection (5\%) [4] [5] [6]. In developing countries in general [7] and in DR Congo (DRC) in particular [8], more particularly in Africa, this condition seems to be linked to Viral Hepatitis, chronic alcoholism and undernutrition [9]. Before 1990, the management (etiological, diagnostic, assessment report, medical decision, and monitoring) of LC in DRC was based exclusively on medical interview, physical/clinical examination and rare laboratory data (biomarkers). The introduction of abdominal ultrasound (aUS) in Kinshasa has profoundly changed the diagnostic strategies for LC.

Based on high diagnostic accuracy of aUS to detect LC in comparison with liver biopsy/Golden, [10], its information is a useful supplement to the clinical and laboratory workup in the LC first line in the poor DR Congo [11]. Indeed, pathologists and liver biopsy are not available for the diagnosis of cirrhosis [12]. 
Thus, this study was initiated with the aim at identifying and assessing the diagnostic performance of LC-related behaviour risks, symptoms, signs, haematological and biochemical test compared to aUS surrogate Gold standard.

\section{Material and Methods}

\subsection{Study Setting and Design}

This was a mixed (secondary analysis, cross sectional, imaging, series) approaches of consecutive patients treated for chronic liver disease according the flowchart (Figure 1). The secondary analysis retrospectively collected demographics and Bioclinical data from the medical records of patients treated between January 1, 1990 and December 31, 2004 at the gastroenterology unit of the department of internal medicine, University Clinics of Kinshasa (CUK), municipality council of Lemba, city of Kinshasa province, DRC. Were eligible (target population), the patients attending consecutive series of follow up for different liver conditions in the same period and the 3 settings of the study period.

\subsection{Study Population}

The study population concerned all patients Liver cirrhosis in the city of Kinshasa. The sampling was exhaustive to include all consecutive patients was logically considered (no calculated size in a huge clinical population $\geq 30$ patients for epidemiological studies).The following clinical variables of interest were preceded: age, gender, abdominal pain, abdominal bloating, physical asthenia, jaundice, fever, melena, collateral circulation, clinical hepatomegaly, liver pain, firm consistency of the liver; the irregular surface of the liver, sharp edge, prehepatic dullness, declining dullness; wave sign, icicle sign, and ascites.

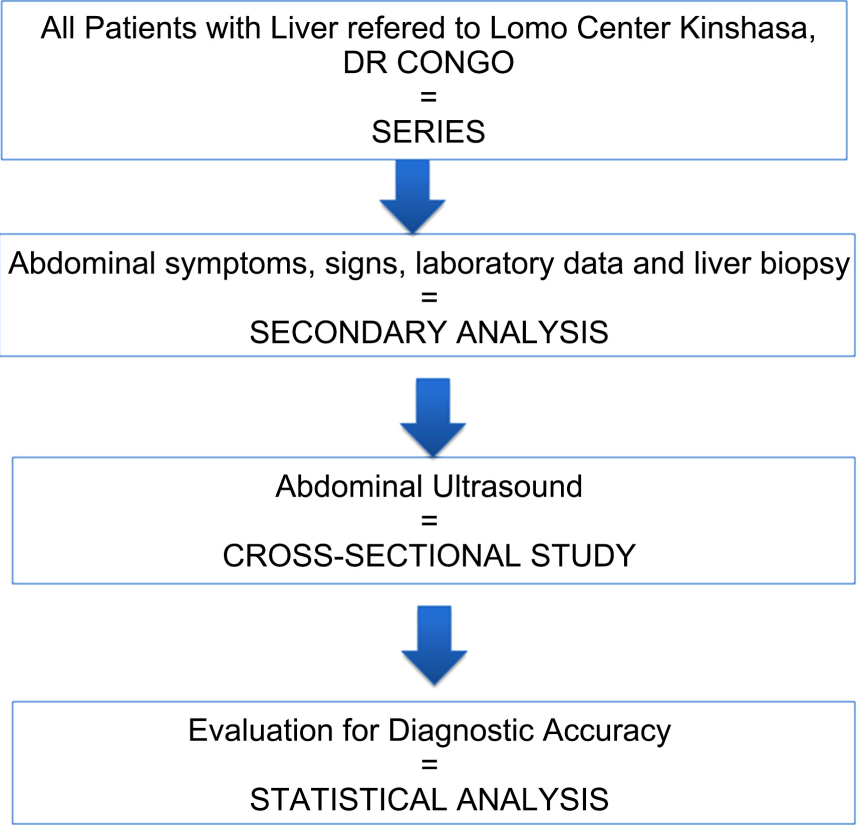

Figure 1. Flow chart of the mixed analysis. 
The following blood tests from the routine laboratory methods (circulating biological/haematological and biochemical measures or biomarkers) were also considered: haemoglobin, haematocrit, white cells count, erythrocyte rate sedimentation (ERS), prothrombin, liver transaminases activities (AST and ALT), total bilirubin, direct bilirubin, indirect bilirubin, total protein, albumin, and fibrinogen.

All aUS examinations were performed within 1 week of the liver histopathology from the Service of Anatomopathology, Faculty of Medicine, University of Kinshasa, DRC, using Prosound SSD-5000SV (Aloka Co., Wisconsin, USA) equipped with a 3.5 - 5.0 MHZ convex probe at LOMO Center, Kinshasa Limete, DRC. The aUS findings made by the first author (SMM unaware of the aUS, clinical, and biomarkers diagnoses) during the cross-sectional study were reviewed by two seniors in imaging research (LMB and MLTSH, co-promotors of the first author) among 30 patients (perfect inter-observer variability, validity, and objectivity).

Using ultrasongraphy, the LC was defined by aUS score graded according to the gallbladder, the right kidney, the liver echogenicity, and the spleen (disharmonious changes in the size of the liver, finely bumpy liver contours, macronodules easier to visualize than micronodules/ 1 to $3 \mathrm{~mm}$, hepatic parenchyma being homogeneous or heterogeneous).

\subsection{Statistical Analysis}

Systematic cleaning of the file data was carried out by LOMO Team throught of the completeness test and the consistency test for the harmonization and validation of the data. To assess the diagnostic accuracy of each clinical and biological parameter, Receiver-Operating characteristics (ROC) curves were obtained and the areas under the ROC curves (AUC with standard error and 95\% confidence intervals/CI) were computed using the sensitivity, the specificity, and the Kappa static. The univariate analysis used a contingency table to compare the proportions by Chi-square while the Student-Test compared the means of different quantitative variables between 2 groups (group for LC as the dependent variable vs. group of clinical and biomarkers/independent variables) with Odds-ratio (OR) and 95\% CI. Then, after excluding some confusion variables out the equation, the multivariate Logistics binary regression analysis was to identify the most important and significant independent determinants(adjusted OR and 95\%CI) of LC. All analyses were computed by the Statistical Package for Social Sciences (SPSS) software (New York, USA), Version 25 (NEW YORK, USA). P < 0.05 was the difference for statistical significance.

\subsection{Ethical Considerations}

The data was collected anonymously and confidentially. The privacy and personality of the respondents were safeguarded. The three fundamental principles of ethics were respected at the time of the study: the principle of respect for the person, that of beneficence and that of justice. 


\section{Results}

In total, the data of 200 patients were reviewed.

\subsection{General Characteristics of Patients}

Demographic data

The study population was divided into 142 men and 58 women with a sex ratio close to 3 Men: 1 Woman. The mean age was $47.8 \pm 14.3$ years (range 16 and 82). Out of the democraphics, risky behavior, and the clinical data, Table 1 presents some significant $(\mathrm{P}<0.05)$ univariate associated clinical factors of aUS LC in the study population such as male sex, age $\geq 45$ years, presence of abdominal bloating, leg oedema, excessive alcohol intake, resonant tympanic abdomen, wave sign and icicle sign. However, the rest of clinical variables of interest were not $(\mathrm{P}>0.05)$ associated with aUS LC (results not presented).

Table 1. Univariate associated clinical factors of aUS LC in the study population.

\begin{tabular}{|c|c|c|c|}
\hline Variable & aUS LC \% (n) & OR $(95 \% \mathrm{CI})$ & $\mathrm{p}$ \\
\hline \multicolumn{4}{|l|}{ Age } \\
\hline$<45$ years & $30.4(24 / 79)$ & 1 & \\
\hline$\geq 45$ years & $52.1(63 / 121)$ & $17.0(1.2-25.0)$ & 0.002 \\
\hline \multicolumn{4}{|l|}{ Gender } \\
\hline Female & $29.3(17 / 58)$ & 1 & \\
\hline Male & $49.3(70 / 142)$ & $2.4(1.2-4.5)$ & 0.007 \\
\hline \multicolumn{4}{|l|}{ Abdominal Bloating } \\
\hline No & $38.3(49 / 128)$ & 1 & \\
\hline Yes & $52.8(38 / 72)$ & $1.8(1.01-3.2)$ & 0.033 \\
\hline \multicolumn{4}{|l|}{ Leg oedema } \\
\hline No & $36.1(52 / 144)$ & 1 & \\
\hline Yes & $62.5(35 / 56)$ & $3.0(1.6-5.6)$ & 0.001 \\
\hline \multicolumn{4}{|c|}{ Excessive Alcohol intake } \\
\hline No & $36.0(31 / 86)$ & 1 & \\
\hline Yes & $49.1(56 / 114)$ & $1.7(1.1-3.0)$ & 0.044 \\
\hline \multicolumn{4}{|c|}{ Resonant Tympanic Abdomen } \\
\hline No & $37.2(51 / 137)$ & 1 & \\
\hline Yes & $57.1(36 / 63)$ & $2.3(1.2-4.1)$ & 0.007 \\
\hline \multicolumn{4}{|l|}{ Wave sign } \\
\hline No & $38.2(60 / 157)$ & 1 & \\
\hline Yes & $62.8(27 / 43)$ & $2.7(1.4-5.5)$ & 0.003 \\
\hline \multicolumn{4}{|l|}{ Icicle sign } \\
\hline Non & $39.5(70 / 177)$ & 1 & \\
\hline Yes & $73.9(17 / 23)$ & $4.3(1.6-11.5)$ & 0.002 \\
\hline
\end{tabular}


After excluding confounders (age, sex, resonnant tympanic abdomen and wave sign) out the equation of the multivariate logistics binary regression analysis, only excessive alcohol intake (adj. $\mathrm{OR} \approx 4 ; \mathrm{P}<0.01$ ), leg oedema (adj. OR = 5; $\mathrm{P}<0.0001)$ and icicle sign (adj. OR $=15 ; \mathrm{P}<0.0001)$ were the most important and significant independent determinants of aUS LC in the study population (Table 2). Thus, the prediction of aUS LC at clinics university of Kinshasa might be under the following equation $\mathrm{Y}=-2.783+4 \mathrm{x}$ Excessive alcohol intake (yes) + $5 \mathrm{X}$ Leg oedema (yes) + 15X Icicle sign (yes).

\subsection{Independent Discriminant Clinical Spectrum}

After adjustment in multivariate analysis of logistic regression, excessive alcohol intake (aOR: 3.5 95\% CI: 1.4 - 8.8), leg oedema (aOR: 5.3 95\% CI: 2.2 - 12.8) and the jaundice sign (aOR: 15.1 95\% CI: 5.2 - 44) were independent factors predicting liver cirrhosis (Table 2).

\subsection{Diagnostic Accuracy/Performance of Circulating Hematologic and Biochemical Biomarkers}

Except for hematocrit and the significant and high diagnostic accuracy detecting aUS LC were age $\geq 45$ years, ERS $\geq 60 \mathrm{~mm} / 1^{\text {st }} \mathrm{H}$, indirect bilirubin $\geq 2 \mathrm{mg} / \mathrm{dL}$, prothrobin $<60 \%$, hemoglobin $<10 \mathrm{~g} / \mathrm{dL}$, white cells count $<4000 / \mathrm{mm}^{3}$, lymphocyte $<20 \%$, albumin $<30 \mathrm{~g} / \mathrm{L}$, total protein $<70 \mathrm{~g} / \mathrm{L}$, fibrinogen $<150,000$ $\mathrm{mg} / \mathrm{dL}, \mathrm{AST} \geq 60 \mathrm{IU} / \mathrm{L}, \mathrm{ALT} \geq 55 \mathrm{IU} / \mathrm{L}, \mathrm{GGT} \geq 45 \mathrm{IU} / \mathrm{L}$, neutrophils $\geq 80 \%$ and NLR $\geq 3$ (Table 3 ).

\subsection{ROC Curve of Biomarkers Predicting the Diagnosis of Liver Cirrhosis}

Figures 2(A)-(D) show the ROC curve of biomarkers predicting the diagnosis of Liver cirrhosis.

Table 2. Independent discriminant clinical spectrum of the presence and the absence of liver cirrhosis (LC) among all patients.

\begin{tabular}{lcccc}
\hline $\begin{array}{l}\text { Independent variable } \\
\text { Excessive alcohol Intake }\end{array}$ & $\beta$ & ES & aOR (95\%CI) & P \\
$\quad$ No & & & 1 & \\
Yes & 1.261 & 0.464 & $3.5(1.4-8.8)$ & 0.007 \\
Leg oedema & & & 1 & \\
$\quad$ No & 1.666 & 0.450 & $5.3(2.2-12.8)$ & $<0.0001$ \\
$\quad$ Yes & & & 1 & \\
Jaundice sign & & & & \\
$\quad$ No & 2.716 & 0.544 & $15.1(5.2-44)$ & $<0.0001$ \\
$\quad$ Yes & -2.783 & 0.452 & & \\
Intercept & & & & \\
\hline
\end{tabular}



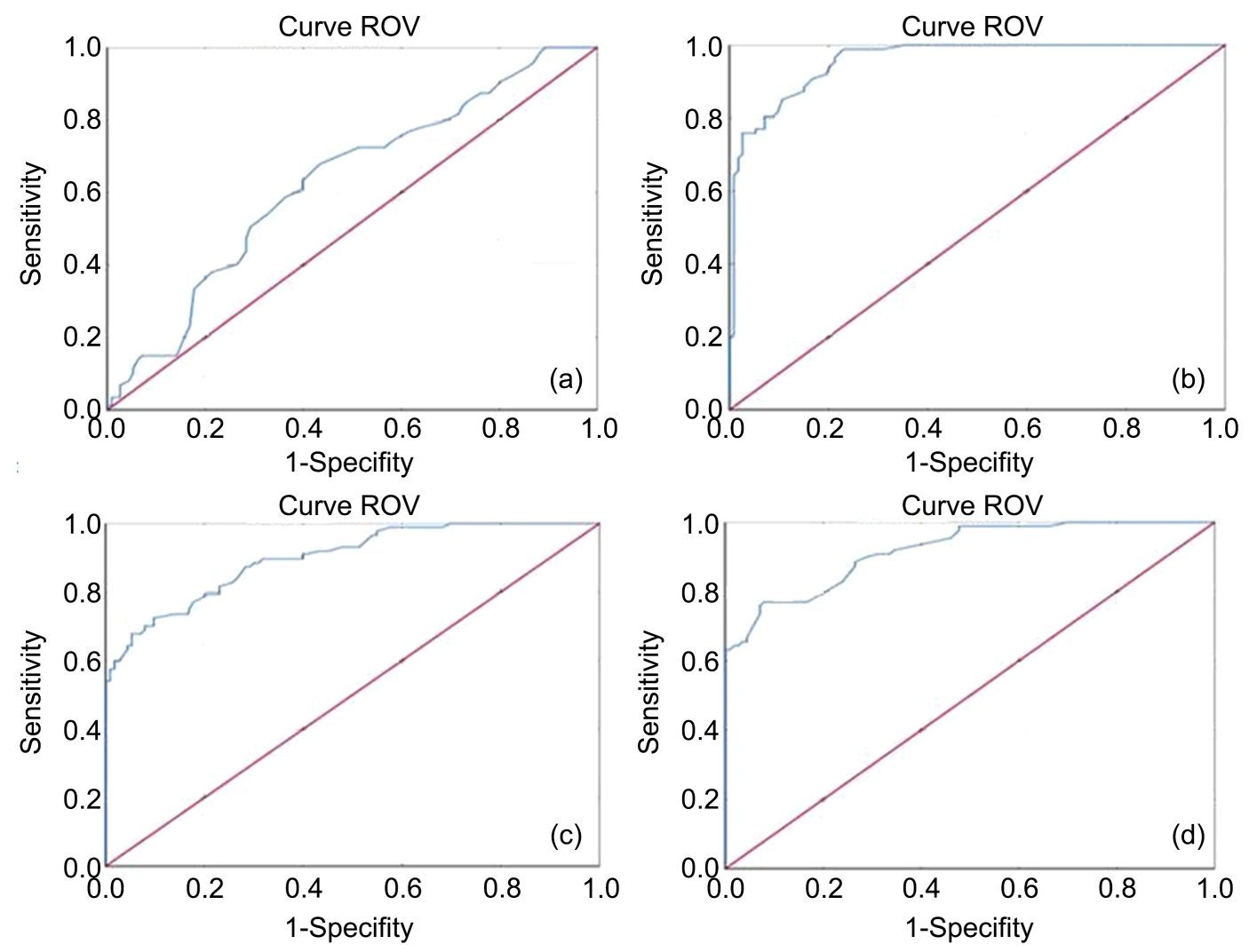

(A)
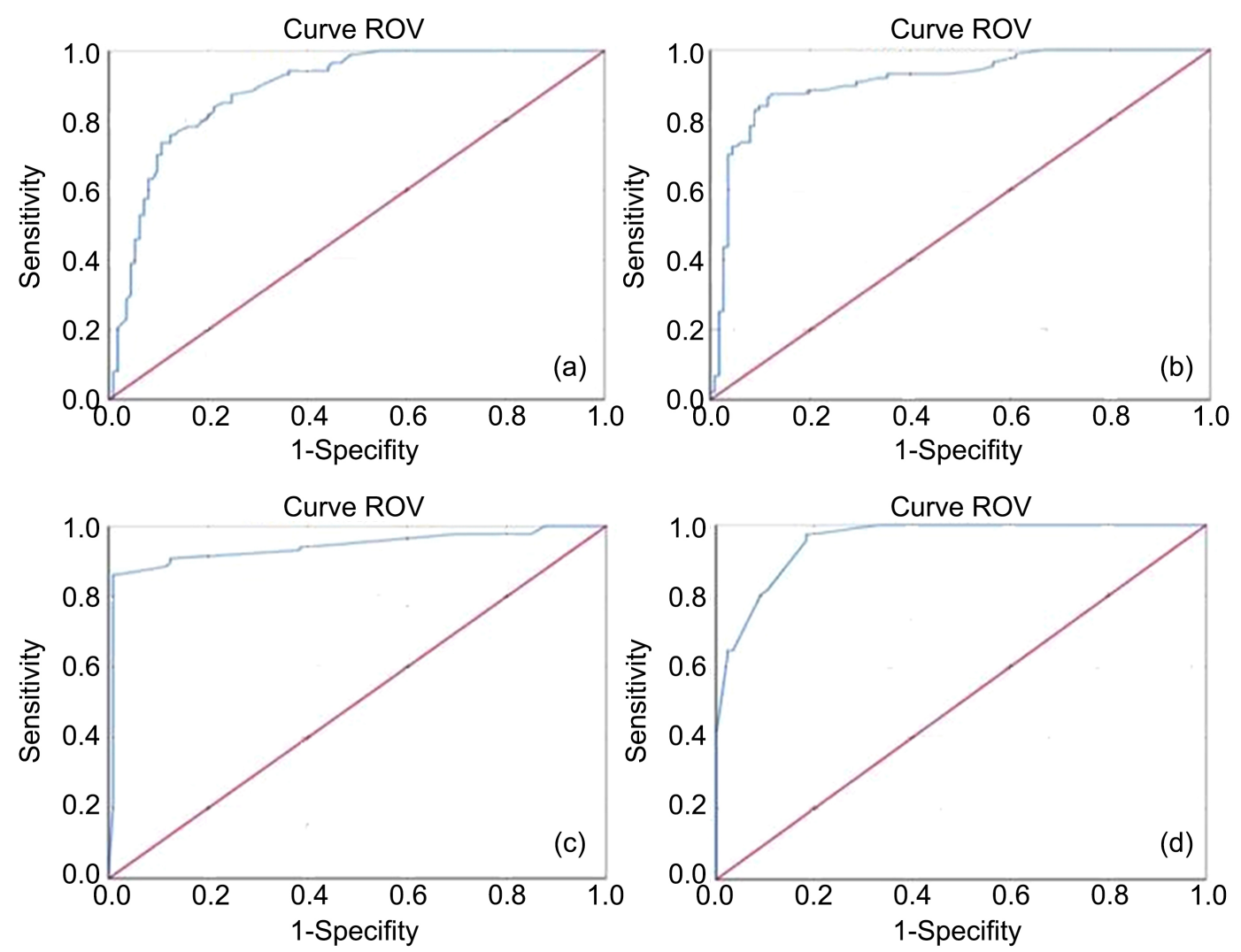

(B) 

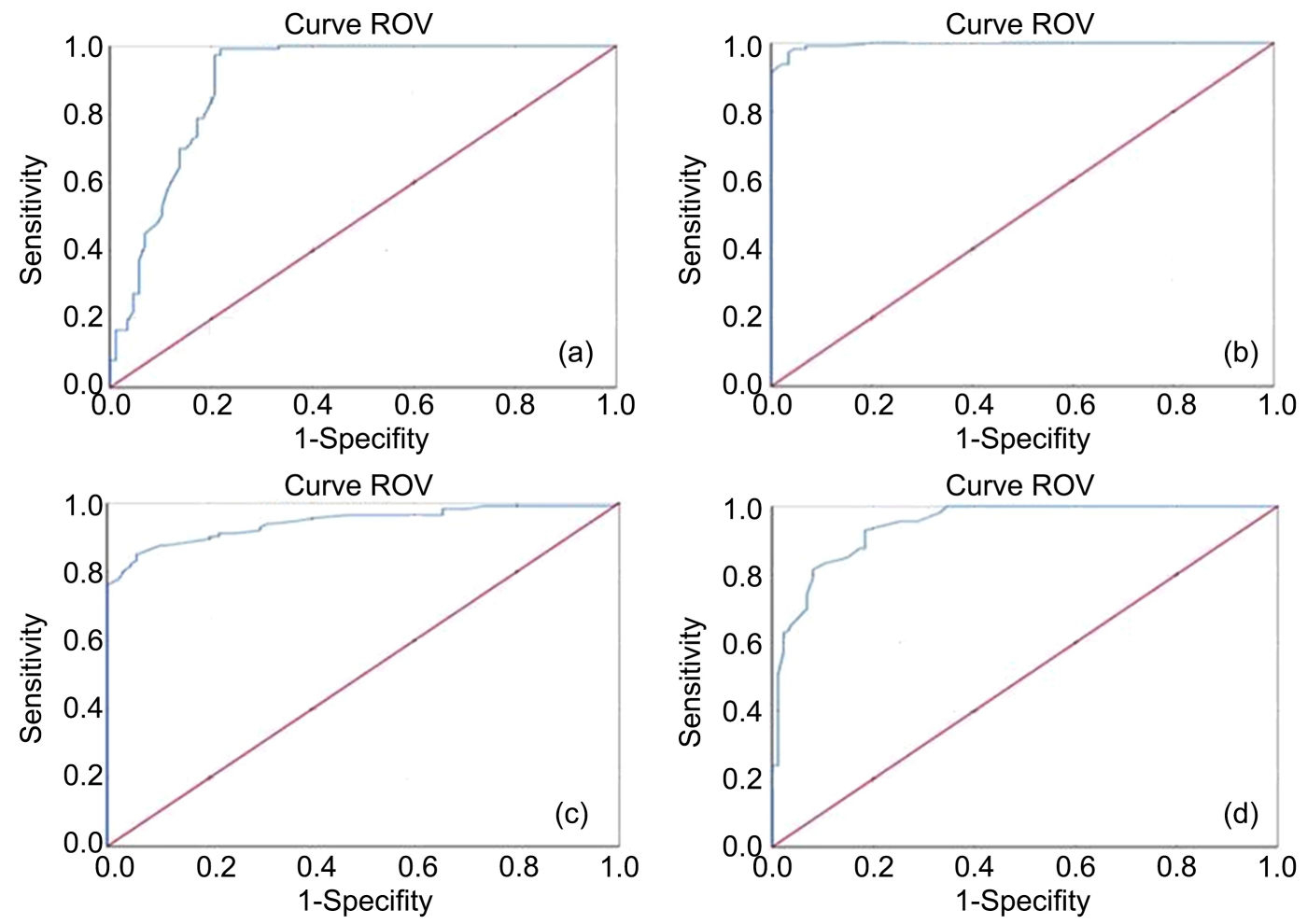

(C)
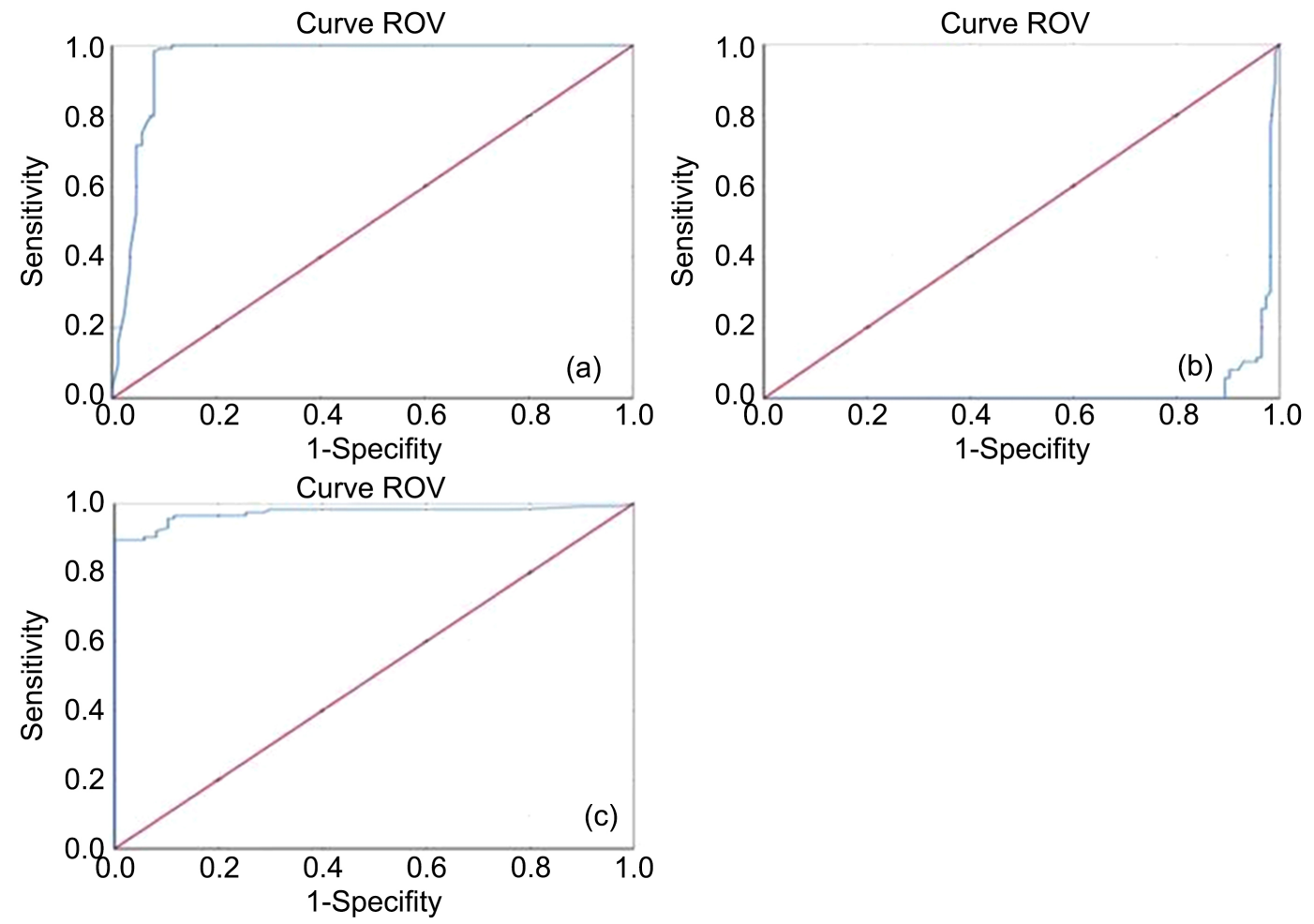

(D)

Figure 2. (A) ROC curve of biomarkers: (a) Age $\geq 45$ years; (b) Neutrophile $\geq 80 \%$; (c) $E R S \geq 60 \mathrm{~mm} / 1 \mathrm{st} \mathrm{H}$; (d) GGT $\geq 45$ IU/L; (B) ROC curve of biomarkers: (a) AST $\geq 60 \mathrm{IU} / \mathrm{L}$; (b) ALAT $\geq 55 \mathrm{IU} / \mathrm{L}$; (c) Indirect Bilirubin $\geq 2 \mathrm{mg} / \mathrm{dL}$; (d) Hemoglobin $<10$ $\mathrm{gr} / \mathrm{Dl}$; (C) ROC curve of biomarkers: (a) White Cells $<4000 / \mathrm{mm}^{3}$; (b) Lymphocytes $<20 \%$; (c) Prothrombine < 60\%; (d) Albumine $<30 \mathrm{gr} / \mathrm{L}$; (D) ROC curve of biomarkers: (a) Total Protein $<70 \mathrm{gr} / \mathrm{L}$; (b) Fibrogen $<150 \mathrm{mg} / \mathrm{dL}$; (c) NLR $\geq 3$. 
Table 3. Diagnostic accuracy/performance of circulating hematologic and biochemical biomarkers for Liver Cirrhosis (LC) compared to abdominal ultrasound (aUS) among all patients suffering chronic liver disease using ROC.

\begin{tabular}{|c|c|c|c|c|c|}
\hline Variable & $\begin{array}{l}\text { Sensitivity } \\
\text { (\%) }\end{array}$ & $\begin{array}{c}\text { Specificity } \\
\text { (\%) }\end{array}$ & Kappa & AUC $(95 \% C I)$ & $\mathbf{P}$ \\
\hline Age $\geq 45$ years & 70.0 & 57.0 & 0.200 & $\begin{array}{c}0.629 \pm 0.040 \\
(0.552-0.706)\end{array}$ & 0.002 \\
\hline Neutrophils $\geq 80 \%$ & 72.4 & 97.0 & 0.718 & $\begin{array}{c}0.957 \pm 0.042 \\
(0.933-0.981)\end{array}$ & 0.0001 \\
\hline $\mathrm{ESR} \geq 60 / \mathrm{mm}^{3}$ & 88.5 & 70.0 & 0.566 & $\begin{array}{c}0.899 \pm 0.021 \\
(0.857-0.941)\end{array}$ & 0.0001 \\
\hline $\mathrm{GGT} \geq 45(\mathrm{IU} / \mathrm{L})$ & 83.0 & 76.0 & 0.570 & $\begin{array}{c}0.918 \pm 0.019 \\
(0.881-0.954)\end{array}$ & 0.0001 \\
\hline $\mathrm{AST} \geq 60(\mathrm{IU} / \mathrm{L})$ & 70.1 & 90.0 & 0.606 & $\begin{array}{c}0.889 \pm 0.023 \\
(0.844-0.934)\end{array}$ & 0.0001 \\
\hline $\mathrm{ALT} \geq 55(\mathrm{IU} / \mathrm{L})$ & 84.0 & 90.0 & 0.745 & $\begin{array}{c}0.912 \pm 0.022 \\
(0.889-0.954)\end{array}$ & 0.0001 \\
\hline $\begin{array}{l}\text { Indirect Bilirubin } \\
\quad \geq 2(\mathrm{mg} / \mathrm{dL})\end{array}$ & 91.0 & 88.0 & 0.525 & $\begin{array}{c}0.940 \pm 0.020 \\
(0.901-0.979)\end{array}$ & 0.0001 \\
\hline $\begin{array}{c}\text { Hemoglobin } \\
<10(\mathrm{~g} / \mathrm{dL})\end{array}$ & 96.0 & 82.0 & 0.783 & $\begin{array}{c}0.955 \pm 0.013 \\
(0.942-0.968)\end{array}$ & 0.0001 \\
\hline
\end{tabular}

\subsection{Univariate Analysis at Comparing Mean Values of Biomarkers between}

Indeed, the mean levels of hemoglobin, white cells count, lymphocytes, prothrombin, fibrinogen, albumin and total protein were significantly $(\mathrm{P}<0.05)$ lower in the presence of aUS LC than thoses in the absence of aUS LC whereas the mean levels of ERS, neutrophils, NLR, GGT, AST and ALT were significantly $(\mathrm{P}<0.05)$ higher in the presence of aUS than those in the absence of aUS LC (Table 4).

\subsection{Independent Discriminant Laboratory Data of Liver Cirrhosis}

In not including neutrophils and lymphocytes within the equation. After excluding confounders (age, white cells count, total protein, albumin, fibrinogen, GGT and ALT), out the equation of the multivariate Logistic binary regression analysis only ERS $\geq 60 \mathrm{~mm} / 1^{\text {st }} \mathrm{H}$ (adj. OR $\approx 11 ; \mathrm{P}<0.055$ ), AST $\geq 60 \mathrm{IU} / \mathrm{L}$ (adj. $\mathrm{OR}=10 ; \mathrm{P}<0.059$ ), indirect bilirubin $\geq 2 \mathrm{mg} / \mathrm{dL}$ (adj. $\mathrm{OR}=7 ; \mathrm{P}<0.05$ ), prothrombin $<60 \%$ (adj. OR $=12$; $\mathrm{P}<0.05$ ), hemoglobin $<10 \mathrm{~g} / \mathrm{dL}$ (adj. $\mathrm{OR}=17$; $\mathrm{P}<$ $0.05)$ and NLR $\geq 3$ (adj. OR $=38$ ) were the most important and significant independent determinant of aUS LC (Table 5).

Thus, the prediction of aUS LC at Clinics University of Kinshasa might be under the following equation $\mathrm{Y}=-6.911+11 \times \mathrm{ERS} \geq 60 \%$ (yes) $+10 \times$ AST $\geq$ $60 \mathrm{IU} / \mathrm{L}$ (yes) $+7 \times$ indirect bilirubin $\geq 2 \mathrm{mg} / \mathrm{dL}$ (yes) $+12 \times$ prothrombin $<$ $60 \%$ (yes) $+17 \times$ hemoglobin $<10$ g/L (yes) $+38 \times N L R \geq 3$ (yes) 
Table 4. Univariate analysis at comparing mean values of biomarkers between the presence $(n=27)$ and the absence of Liver Cirrhosis $(L C)$.

\begin{tabular}{cccc}
\hline Variables of interest & $\begin{array}{c}\text { Presence of LC } \\
\text { Mean } \pm \text { SD/ESM }\end{array}$ & $\begin{array}{c}\text { Absence of LC } \\
\text { Mean } \pm \text { SD/ESM }\end{array}$ & p-value \\
\hline Age (years) & $51.5 \pm 13.2$ & $44.9 \pm 14.4$ & $<0.001$ \\
Hemoglobin (g/dL) & $7.8 \pm 1.8$ & $12.1 \pm 1.6$ & $<0.0001$ \\
White cells (/mm3) & $3799 \pm 2884$ & $9747 \pm 6748$ & $<0.0001$ \\
Neutrophils (\%) & $83 \pm 13.2$ & $29.9 \pm 23.2$ & $<0.0001$ \\
Lymphocytes (\%) & $13.8 \pm 5.9$ & $73.9 \pm 21.7$ & $<0.0001$ \\
ESR(mm/1stH) & $163.9 \pm 83.2$ & $40.8 \pm 3.9$ & $<0.0001$ \\
Prothrobin (\%) & $36 \pm 16.5$ & $76.1 \pm 16.8$ & $<0.0001$ \\
Albumin (g/L) & $15.7 \pm 10.4$ & $42.9 \pm 12.4$ & $<0.0001$ \\
GGT (IU/L) & $71.4 \pm 22.2$ & $31.8 \pm 13.4$ & $<0.0001$ \\
AST (IU/L) & $118.3 \pm 72$ & $34.2 \pm 4.8$ & $<0.0001$ \\
ALT (IU/L) & $147 \pm 90.6$ & $31 \pm 4.3$ & $<0.0001$ \\
Indirect Bilirubin (mg/dL) & $6 \pm 2$ & $1.4 \pm 1.1$ & $<0.0001$ \\
Total protein (g/L) & $15.5 \pm 2.3$ & $79.3 \pm 15.4$ & $<0.0001$ \\
Fibrinogen (mg/dL) & $26 \pm 3.3$ & $137.5 \pm 13$ & $<0.0001$ \\
NLR & $7.1 \pm 3$ & $0.6 \pm 0.07$ & $<0.0001$ \\
\hline
\end{tabular}

Table 5. Independent discriminant laboratory data of the presence and the absences of Liver Cirrhosis (LC) among all patients.

\begin{tabular}{|c|c|c|c|c|}
\hline Independent Variable & $\beta$ & ES & aOR $(95 \% \mathrm{CI})$ & $\mathrm{p}$ \\
\hline \multicolumn{5}{|l|}{ ERS } \\
\hline$<60 \mathrm{~mm} / 1$ st $\mathrm{H}$ & & & 1 & \\
\hline$\geq 60 \mathrm{~mm} / 1 \mathrm{st} \mathrm{H}$ & 2.354 & 1.050 & $10.5(1.3-82.4)$ & 0.025 \\
\hline \multicolumn{5}{|l|}{ AST } \\
\hline$<60 \mathrm{IU} / \mathrm{L}$ & & & 1 & \\
\hline$\geq 60 \mathrm{IU} / \mathrm{L}$ & 2.338 & 1.068 & $10.4(1.3-84)$ & 0.029 \\
\hline \multicolumn{5}{|l|}{ Indirect Bilirubin } \\
\hline$<2 \mathrm{mg} / \mathrm{dL}$ & & & 1 & \\
\hline$\geq 2 \mathrm{mg} / \mathrm{dL}$ & 1.898 & 0.970 & $6.7(1-44.7)$ & 0.049 \\
\hline \multicolumn{5}{|l|}{ Prothrombin } \\
\hline$\geq 60 \%$ & & & 1 & \\
\hline$<60 \%$ & 2.485 & 1.009 & $12(1.7-86.8)$ & 0.014 \\
\hline \multicolumn{5}{|l|}{ Hemoglobin } \\
\hline$\geq 10 \mathrm{~g} / \mathrm{dL}$ & & & 1 & \\
\hline$<10 \mathrm{~g} / \mathrm{dL}$ & 2.832 & 1.263 & $17(1.4-202)$ & 0.025 \\
\hline \multicolumn{5}{|l|}{ NLR } \\
\hline$<3$ & & & 1 & \\
\hline$\geq 3$ & 3.648 & 1.263 & $38.4(3.2-456)$ & 0.004 \\
\hline Intercept & -6.911 & 1.482 & & $<0.0001$ \\
\hline
\end{tabular}




\section{Discussion}

The present study compared the levels of diagnostic accuracy of some Bioclinical markers for Liver cirrhosis (LC) detection using a abdominal ultrasound as a surrogate Gold standard because of its very high sensitivity [13] and the increasingly rare indications for liver biopsy for histopathological study [14].

\subsection{Demographic Data and Risky Behaviour}

In this study population, the male vulnerability was very marked for aUS LC. The sex ratio was 3 men: 1 woman. Indeed, the male vulnerability was also reported in Italian patients from Europe [15], some sub-African countries [16], and in Pakistan from Asia [17]. Excessive alcohol consumption, one of the significant independent determinants of aUS LC in the present study, was also reported higher risk for liver cirrhosis in men than in women from Italy [18].

This study from DRC and the studies from other African countries demonstrated elsewhere in Africa [19], patients with hepatic cirrhosis and primary liver cancer are young adults [20] [21]. In Europe, on the other hand, LC patients are older around 60 years [2] [13]. However, Shaista et al. in Pakistan from Asia, found an average age of $39.54 \pm 12.77$ years [22] and younger than a mean age of $51.5 \pm 13.2$ years of LC patients from the DRC study and age of 45 years from Republic of Central Africa [23] where men do more drink excessive alcohol/binge than women do [24].

\subsection{Bioclinical Parameters Discriminating in Hepatic Cirrhosis}

There are many controversies on clinical examination of the liver and some blood liver tests related to LC with and without aUS [25] [26] [27] [28]. The researchers from the present work and those from the literature (Singini REF) do analyse age, gender, abdominal pain, abdominal bloating, physical asthenia, jaundice, fever, melena, collateral circulation, clinical hepatomegaly, liver pain, firm consistency of the liver; the irregular surface of the liver, sharp edge, prehepatic dullness, declining dullness; wave sign, icicle sign, liver surface nodularity, ascites, and blood tests such as haemoglobin, haematocrit, white cells count, erythrocyte rate sedimentation(ERS), prothrombin, liver transaminases activities (AST and ALT), total bilirubin, direct bilirubin, indirect bilirubin, total protein, albumin, and fibrinogen.

Non-disturbance of hepatic tests (AST and ALT) has already been reported in Africans with liver cirrhosis in Bangui in the Central African Republic [29]. Hung Sub Lee et al in Korea, in a study on the prediction of liver cirrhosis by ultrasound and usual blood biomarkers in 2010, also recorded non-disturbance of liver transaminases activities [30].

\subsection{Diagnostic Performance of Biomarkers to Detect Liver Cirrhosis versus aUS}

Thanks to the evidence from the literature [31] [32] [33] [34] and to our know- 
ledge, the present study used ROC and multivariate logistics binary analysis to show high to excellent diagnostic accuracy of age $\geq 45$ years, haemoglobin $<10$ $\mathrm{gr} / \mathrm{dL}$, white cell count $<4000 / \mathrm{mm}^{3}$, neutrophils $\geq 80 \%$, lymphocytes $<20 \%$, ERS $\geq 60 \mathrm{~mm} / 1^{\text {st }} \mathrm{H}$, albumin $<30 \mathrm{gr} / \mathrm{L}, \mathrm{GGT} \geq 45 \mathrm{IU} / \mathrm{L}, \mathrm{AST} \geq 60 \mathrm{IU} / \mathrm{L}$, ALT $\geq$ $55 \mathrm{IU} / \mathrm{L}$, indirect bilirubin $\geq 2 \mathrm{mg} / \mathrm{dL}$, total protein $<70 \mathrm{gr} / \mathrm{L}$, fibrinogen $<150$ $\mathrm{mg} / \mathrm{dL}, \mathrm{NLR} \geq 3$ to detect aUS LC.

\subsection{Strengths and Limitations of the Study}

The present study had the following strengths: LC might be predicted by routine blood tests without special equipment, experienced physicians reviewed non-invasive and affordable cost aUS, liver biopsy obtained, findings of $30 \mathrm{pa}-$ tients to objectify the subjective sonographic images, mean measures during the cross-sectional approach, and mathematical models with DRC-specific cut-offs of analysed biomarkers.

However, the present study had limitations to some degree as follows: a retrospective secondary approach without calculated sample size/number of patients relatively small, lack of sequential measurements of representative values during a follow-up, Coupling Doppler to ultrasound, and gray-scale would have allowed the definition of portal hypertension and portal vein thrombosis [35] in hepatic cirrhosis [36].

\section{Conclusions}

The non-invasive aUS combined with the current clinical spectrum and biomarkers might be used as a surrogate Gold standard test for the management of chronic liver disease in poor Central Africa.

The development of the model consisting of ERS $\geq 60 \mathrm{~mm} / 1^{\text {st }} \mathrm{H}$, AST $\geq 60$ $\mathrm{IU} / \mathrm{L}$, indirect bilirubin $\geq 2 \mathrm{mg} / \mathrm{dL}$, prothrombin $<60 \%$, haemoglobin $<10$ $\mathrm{gr} / \mathrm{dL}$, and NLR $\geq 3$ may be useful at identifying aUS LC with a high level of accuracy in daily practice Clinics of University of Kinshasa, DRC in combining interview, clinical examination, ultrasound and blood biomarker testing to improve LC management.

\section{Acknowledgements}

We thank all who participated in the study.

\section{Author's Contributions}

SMM and ANN designed and analyzed the statistical data for the study. MLT, SMN, CMN, SMF, ATW, VTN, ANO, ICD, EM and LMB supervised the study. All authors have read and approved the final and revised version of the manuscript.

\section{Conflicts of Interest}

The authors declare no conflicts of interest. 


\section{References}

[1] Garcia-Tsao, G. (2015) Natural History of Cirrhosis. In: Complications of Cirrhosis, Springer, Cham, 13-20. https://doi.org/10.1007/978-3-319-13614-1 2

[2] Zhai, M.M., et al. (2021) The Burden of Liver Cirrhosis and Underlying Etiologies: Reaction from the Global Burden of Disease Study 2017. Aging, 13, 279-300. https://doi.org/10.18632/aging.104127

[3] De Carvalho, J.R., Villela-Nogueira, C.A., Perez, R.M., Portugal, F.B., Flor, L.S., Campos, M.R., et al. (2017) Burden of Chronic Viral Hepatitis and Liver Cirrhosis in Brazil-The Brazilian Global Burden of Disease Study. Annals of Hepatology, 16, 893-900. https://doi.org/10.5604/01.3001.0010.5280

[4] Westbrook, R.H. and Dusheiko, G. (2014) Natural History of Hepatitis C. Journal of Hepatology, 61, S58-S68. https://doi.org/10.1016/j.jhep.2014.07.012

[5] GBD 2017 Cirrhosis Collaborators (2020) The Global, Regional, and National Burden of Cirrhosis by Cause in 195 Countries and Territories, 1990-2017: A Systematic Analysis for the Global Burden of Disease Study 2017. The Lancet Gastroenterology and Hepatology, 5, 245-266. https://doi.org/10.1016/S2468-1253(19)30349-8

[6] Ouavene, J.O., Koffi, B., Mobima, T., Bekondji, C., Massengue, A. and Guenebem, A.K. (2014) Cirrhoses du foie à l'hopital de l'amitié de Bangui aspects épidémiologiques, cliniques, échographiques et problèmes de diagnostic. Journal African d Imagerie Médicale, 5, 1-12.

[7] Roth, G.A., Abate, D. and Abate, K.H. (2018) Mortalité mondiale, régionale et nationale selon l'âge, le sexe pour 282 causes de décès dans 195 pays et territoires, 1980-2017: Une analyse systématique pour l'étude Global Burden of Disease 2017. The Lancet, 392, 1736-1788. https://doi.org/10.1016/S0140-6736(18)32203-7

[8] Mbendi, C.N., Nkodila, A.N., Zingondo, J.C.B., Manangama, C.N., Taty, P.L., Ngoma, J.A., et al. (2018) Multicentric Study on Epidemiological, Clinical and Progressive Aspects of Liver Cirrhosis in Kinshasa. Annals of African Medicine, 11, e652.

[9] Kyelem, C.G., Sawadogo, A., Yaméogo, TM., Nikièma, Z., Youl, S. and Ouédraogo, S.M. (2011) Le cancer primitif du foie au Centre Hospitalier Universitaire de Bobo-Dioulasso: Aspects épidémiologiques, diagnostiques et évolutifs. Carcinol Clin Afrique, 10, 24-28.

[10] Menu, Y. and Amouretti, M. (1998) Abdominal Ultrasound (Pelvis Excluded): Indications for First Line. Gastroenterologie Clinique et Biologique, 22, 329-342.

[11] Zwiebel, W.J. (1995) Sonographic Diagnosis of Diffuse Liver Disease. Seminars in Ultrasound, CT and MRI, 16, 8-15. https://doi.org/10.1016/0887-2171(95)90011-X

[12] Agostino, C., Alice, C., Silvia, P., Mirella, F., Sara, M., Marco, A., et al. (2005) Accuracy of a Predictive Model for Severe Hepatic Fibrosis or Cirrhosis in Chronic Hepatitis C. World Journal of Gastroenterology, 11, 7318-7322. https://doi.org/10.3748/wjg.v11.i46.7318

[13] Endo, M., Soroida, Y. and Sato, M. (2017) Ultrasound Evaluation of Liver Stiffness: Accuracy of Ultrasound Imaging for the Prediction of Liver Cirrhosis as Evaluated Using a Liver Stiffness Measurement. Journal of Medical and Dental Sciences, 64, 27-34.

[14] Choong, C., Venkatesh, S.K. and Siew, E.P.Y. (2012) Accuracy of Routine Clinical Ultrasound for Staging of Liver Fibrosis. Journal of Clinical Imaging Science, 2, 58. https://doi.org/10.4103/2156-7514.101000 
[15] D’onofrio, M., Martone, E., Brunneli, S., Faccioli, N., Zamboni, G., Zagni, I., et al. (2005) Accuracy of Ultrasound in the Detection of Liver Fibrosis in Chronic Viral Hepatitis. La Radiologia Medica (Torino), 110, 341-348.

[16] Atipo-Ibara, B.I., Ondele-Ngoli, A. and Deby, G. (2004) Le coût financier de la prise en charge hospitalière de la Cirrhose et de ses complications au CHU de Brazzaville. Medecine Tropicale, 64, 50-52.

[17] Serme, A.K., Ilboudo, P.D., Bougouma, A. and Soumbu (2002) La Cirrhose au CHU de Y AlGADO OUEDRAOGO. Aspect Epidémiologique et clinique. Medecine d Afrique Noire, 11, 481-486.

[18] Rossi, E., Adams, L., Prins, A., Bulsara, M., de Boer, B., Garas, G., et al. (2003) Validation of the FibroTest Biochemical Markers Score in Assessing Liver Fibrosis in Hepatitis C Patients. Clinical Chemistry, 49, 450-454. https://doi.org/10.1373/49.3.450

[19] Ayol-Petty, M., Dith, W. and Kalengay, L.M. (1990) Carcinome Hépatocellulaire sur Cirrhose à propos de 84 observations. Medecine d Afrique Noire, 37, 237-242.

[20] Le Bras, M., Tricolat, R., Clerc, M., Loubiere, R., Beda and Bertrant, E. (1978) Etiological Factors of Primary Liver Cancer in Cote d'Ivoire. Gastroentérologie Clinique et Biologique, 2, 679-688.

[21] Ibara, J.R., Ossendza, R.A. and Okouo, M. (1999) Primary Liver Cancers in Congo: Hospital Study of 558 Cases. Black African Medicine, 46, 394-397.

[22] Afzal, S., Masroor, I. and Beg, M. (2013) Evaluation of Chronic Liver Disease: Does Ultrasound Scoring Criteria Help? International Journal of Chronic Diseases, 2013, Article ID: 326231. https://doi.org/10.1155/2013/326231

[23] Yassibanda, S. (1982) Décompensée et épidémiologiques et cliniques dans deux villes centrafricaines. Thèse, Médecine Bangui (Centrafrique), 53 Décompensée et épidémiologiques et cliniques dans deux villes centrafricaines.

[24] Bonnie, R.T., Anthony, D., Margo, S., Carol, M., Anthony, M.M. and Kabanda, G.K. (2019) Alcohol Use and Sexual Risk Behaviors in the Armed Forces of the Democratic Republic of the Congo. BMC Public Health, 19, 1394. https://doi.org/10.1186/s12889-019-7794-X

[25] Yan, G., Duan, Y. and Ruan, L. (2005) A Study on the Relationships between Ultrasonographic Score and Clinical Score (MELD, CPT) in Cirrhosis. Hepato-Gastroenterology, 52, 1329-1333.

[26] Allan, R., Thoirs, K. and Phillips, M. (2010) Accuracy of Ultrasound to Identify Chronic Liver Disease. World Journal of Gastroenterology. WJG, 16, 3510-3520. https://doi.org/10.3748/wig.v16.i28.3510

[27] Mathiesen, U.L., Franzén, L.E., Aselius, H., Resjö, M., Jacosson, L., Foberg, U., et al. (2002) Increased Liver Echogenicity at Ultrasound Examination Reflects Degree of Steatosis But Not of Fibrosis in Asymptomatic Patients with Mild/Moderate Abnormalities of Liver Transaminases. Digestive and Liver Disease, 34, 516-522. https://doi.org/10.1016/S1590-8658(02)80111-6

[28] Hultcrantz, R. and Gabrielsson, N. (1993) Patients with Persistent Elevation of Aminotransferase: Investigation with Ultrasonography, Radionuclide Imaging and Liver Biopsy. Journal of Internal Medicine, 233, 7-12. https://doi.org/10.1111/j.1365-2796.1993.tb00640.x

[29] Senekian, V.P. (2003) Etiologies des Hépatomégalies à l'hôpital de l'Amitié de Bangui. Thèse Médecine Bangui, 1-81.

[30] Hong, S.L., Jai, K.K., Jae, Y.C., Eun, J.H., So-Yeon, A., Jun, H.S., et al. (2010) Predic- 
tion of Compensated Liver Cirrhosis by Ultrasonography and Routine Blood Tests in Patients with Chronic Viral Hepatitis. The Korean Journal of Hepatology, 16, 369-375. https://doi.org/10.3350/kjhep.2010.16.4.369

[31] Maurizio, S., Lydia, G., Melchiorre, C., Anna, L. and Giuseppe, M. (2014) Non Invasive Tools for the Diagnosis of Liver Cirrhosis. World Journal of Gastroenterology, 20, 18131-18150. https://doi.org/10.3748/wjg.v20.i48.18131

[32] Bruix, J. and Sherman, M. (2011) Management of Hepatocellular Carcinoma: An Update. Hepatology, 53, 1020-1022. https://doi.org/10.1002/hep.24199

[33] European Association for the Study of the Liver and European Organisation for Research and Treatment of Cancer (2012) EASL-EORTC Clinical Practice Guidelines: Management of Hepatocellular Carcinoma. Journal of Hepatology, 56, 908-943. https://doi.org/10.1016/j.jhep.2011.12.001

[34] Soresi, M., La Spada, E., Giannitrapani, L., Campagna, E., Di Gesaro, V., Granà, W., et al. (2010) Hepatocellular Carcinoma: Comparison of Two Different Periods at the Same Center. European Journal of Internal Medicine, 21, 127-130. https://doi.org/10.1016/j.ejim.2009.12.011

[35] Heller, M.T. and Tublin, M.E. (2014) The Role of Ultrasonography in the Evaluation of Diffuse Liver Disease. Radiologic Clinics, 52, 1163-1175. https://doi.org/10.1016/j.rcl.2014.07.013

[36] Berzigotti, A. and Piscaglia, F. (2012) Ultrasound in Portal Hypertension-Part 2 and EFSUMB Recommendations for the Performance and Reporting of Ultrasound Examinations in Portal Hypertension. Ultraschall in der Medizin, 33, 8-32. https://doi.org/10.1055/s-0031-1299145 